\title{
Anti-Radicalism Cinema, Developing Character in ELT to Face 4.0 Issue: A Sociolinguistics Study
}

\author{
Aprilian Ria Adisti ${ }^{1}$, Suesthi Maharani ${ }^{2}$, Widyastuti ${ }^{3}$, Wakhidati Nurrohmah Putri \\ \{aprilian@iainsalatiga.ac.id, suesthimaharani@gmail.com, widyastuti.jati@yahoo.com, \\ wakhidputri@iainsalatiga.ac.id\} \\ 1,2,3,4 Institut Agama Islam Negeri (IAIN) Salatiga, Indonesia
}

\begin{abstract}
Over the last decades, in this 4.0 industrial revolution era, an issue of Islamic radical movement brought destructive image for all Muslims in the world. Anti-radicalism education is very important to be taught to eradicate radicalism understanding, especially for the young Indonesian generations. It is important to internalize anti-radicalism education in the learning curriculum. This study connected character education to English Language Teaching by describing the use of anti-radicalism cinema entitled "Nyai Rosyidah, a Radicalism Fortress of Female Santri" in ELT for English Education students in IAIN Salatiga. The content in this cinema was inserted tolerance value from one of the traditional boarding schools in the most tolerant city in Indonesia, where Bu Nyai as the primary role model. This cinema did not only focus on the radicalism content but also on the teaching English in a linguistic context. The result showed that the cinema could develop tolerant character and also strengthened students nationalism. It could be seen from the result of observation during discussion activity and interview after watching the cinema.
\end{abstract}

Keywords: anti-radicalism, cinema, ELT, tolerant, sociolinguistics.

\section{INTRODUCTION}

This study focused on developing the cinema of inter-religious harmony based on gender perspective for teaching English as a Foreign Language (TEFL) in IAIN Salatiga. Indonesia has the largest Muslim community in the world, with a total follower of around 228,608,665. Although it is predominantly Muslim, Indonesia is not an Islamic country nor a secular state that separates religiously and state relations. It is a pluralist country which consists of various tribes, religions, and cultures. On the contrary, the dynamism of life in Indonesia has the potential to increase the conflict of inter-religious harmony. Wahid Foundation, in 2017 also released the survey about the potential for intolerance to unwelcome groups showed that 57.1 percent of the majority of Muslims were intolerant towards the disliked group. This number increased compared to the survey in 2016 with an intolerance rate of 51.0 percent. If tolerance can not be grown well, it will be the potential to increase conflict religion or exploited religion by certain groups [1]. This situation is getting worse from time to time. One of the preventive ways to decrease disunity for young Indonesian generations is by emerging the content of inter-religious harmony as part of the curriculum in education. 
Education in Indonesia as stated in Government Regulation No. 17 year 2010 [2] has the goals to develop students' character to become human beings which are: (1) Religious and fear to the Almighty God, good behavior and personality; (2) Knowledgeable, skilled, critical, creative, and innovative; (3) Healthy, independent, and confident; and (4) Tolerant, sensitive social, democratic and accountable. The purpose of teaching English is not only to make students have the ability to communicate well in English but also to develop students' character. Unfortunately, English material does not give much contribution to support it. For instance, it is rarely found in English material that emerges the content of inter-religious harmony as the manifestation character of tolerant. It is important, therefore, to develop the English interactive digital learning material such as the cinema that can support the goal of teaching English as a Foreign Language in Indonesia. Learning English in the modern era can not be separated from technological developments. Technology in the digital era plays an important role, especially for millennial generations. This generation is characterized by a life that always uses gadgets and internet connection in everyday life. Well-chosen English interactive digital material can be a useful alternative to encourage students' potential in learning English and build their character.

The objectives of this study were to develop the cinema of inter-religious harmony based on gender perspective for teaching English, to implement the cinema of inter-religious harmony based on gender perspective in English teaching and learning process for English Education Students and to analyze how the cinema of inter-religious harmony based on a gender perspective can foster the students' values and character. The result of this study could make a contribution to the English teaching class. It also provided some scientific, practical and pedagogical benefits. Theoretically, this study would enrich references about the concept of emerging the content of inter-religious harmony in teaching English as a Foreign Language for English Education students in IAIN Salatiga. Practically, this cinema could be used to build students' character about religion and tolerance and raise their nationalism. Then pedagogically, in the field of education, this study could benefit students, teachers, and educational authorities.

In the Indonesian context, similar to many other Asian countries, the practical importance of English is recognized but the learning of Western values is not desired [3].To accommodate the objections from the Islamic school community, writers and teachers need to modify English, which is, an imperialistic language [4], into an instrumental language. One of the ways is by emerging the content of character building in English learning material. The previous researches had revealed by academic scholars, such as Briggs conducted the study about how to use technology to increase word recognition ability to students [5]. Meanwhile, Nusir et.al investigated the possibility of enhancing the early education system with multimedia technologies previously developed to teach students at young ages basic skills [6]. Besides, Sanford and Madill researched powerful and significant learning through video gameplay and creation [7]. Zuliati Rohmah therefore offered some ways of integrating authentic materials containing Islamic messages in English teaching [8]. Then, Baharul Islam et. Al created interactive digital learning material for students in Bangladesh [9] and Elfi also analyzed integrating Islamic messages in English teaching for Indonesian Muslim students [10].

There were some novelties in this study compared to previous researches. First, the product of this research was a cinema and could be used in the English teaching and learning process for English Education students at IAIN Salatiga, besides, that Salatiga is the most tolerant city in Indonesia. Second, this research combined elements of English language teaching with character building for students, namely tolerant characters based on gender 
perspective. Third, the use of gender perspective had appeared since this product was to teach sociolinguistics in English teaching, especially about feminism in gender perspective so, the product was still rarely found. Last but not least, this research could be used as a good teaching material, especially in the context of teaching English as a Foreign Language in the digital era. Sociolinguistics was the main theory in this study. It is a study of the relationship between language and society. It is concerned with how language use interacts with or is affected by social factors such as gender, ethnicity, age or social class, for instance. It is the study of choice and "the principal task. Sociolinguistics is to uncover, describe and interpret the socially motivated" choices an individual makes [11]. Sociolinguists are interested in how we speak differently in varying social contexts, and how we may also use specific functions of language to convey social meaning or aspects of our identity. Sociolinguistics teaches us about real-life attitudes and social situations. While in Wikipedia, it is defined that sociolinguistics is the descriptive study of the effect of all aspects of society, including cultural norms, expectations, and context, on the way language is used, and society's effect on language [12]. In this study, sociolinguistics became the main context of those social factors explained above by what Bu Nyai expressed in her behavior and utterances in cinema, A cultural norms were also studied to build anti-radicalism and tolerant characters and attitudes. Those became the theoretical foundation of using digital material in emerging the content of inter-religious harmony into teaching English as a Foreign Language.

\section{METHOD}

As the objective of the study was to develop the cinema of inter-religious harmony to teach English, the appropriate design of the study was Research and Development (R \& D). The major purpose of $\mathrm{R} \& \mathrm{D}$ efforts is not to formulate or test a theory but to develop an effective product for use in educational programs [13]. Furthermore, educational R \& D is a development model in which the findings of the research are used to design new products and procedures, which are systematically field-tested, evaluated, and refined until they meet specified criteria of effectiveness, quality, or similar standard [14]. There are four stages in developing materials of teaching, called 'Four D model', they are: (1) define (learner, task and concepts analysis), design (media and format selection), develop (experts' appraisal or validator), and disseminate (developmental testing and diffusion and adoption) [15]. From those statements, the research framework in this study could be drawn below.

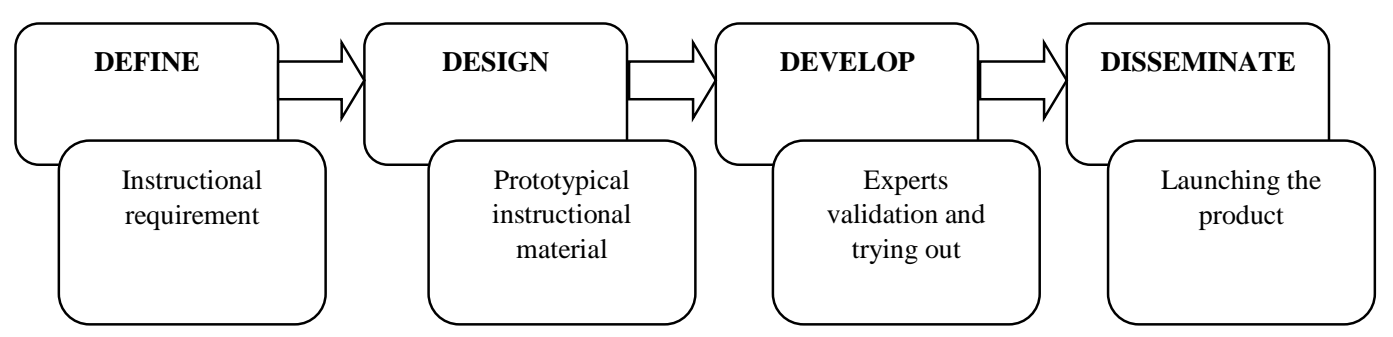

Figure 1. Model of R\&D Design

The instrument used in this study covered: (1) instrument for English lecturer and students' opinion about the content of inter-religious harmony; (2) instrument for examining students' 
perception of watching the cinema (3) instrument for the ICT digital learning experts and English teaching experts. Then, Observation and interview was the data collection technique used in this study.

\section{RESULT AND DISCUSSION}

The product of this research was the documentary cinema entitled "Nyai Rosyidah, a Radicalism Fortress of Female Santri". This cinema was created based on the research on gender perspective about women and radicalism. In this cinema showed a women empowerment in an Islamic boarding school (Pondok Pesantren) of Edi Mancoro, Semarang Regency. Nyai Rosyidah's figure succeeded in breaking the stereotype of Kyai's wive who was usually only respected because of her position as the wife of the leader of the Islamic boarding school. However, she was able to be the agent of change, inviting the santri to love this country (Negara Kesatuan Republik Indonesia) and avoided radicalism. This cinema also taught how as a Muslim must be tolerant of other religions and live peacefully in diversity as the manifestation of inter-religious harmony. The result of this cinema was used in English learning for the first semester students of the English Education Department to build their characters. The Bahasa version was dubbed into English to adjust the language context.

There were four stages in creating the product of the research. Those were explained in the following section in detail. Stage 1: Define: In this stage, we found and collected the available materials in teaching English for English Education students. The materials were taken from the syllabus, and other materials provided in the English Education Department. While to obtain teachers' need, the writers interviewed some English lecturers in IAIN Salatiga. We specifically took English 1 courses for the first semester students of English Education Department since when the writers saw the textbook used by English lecturers, there was the topic of anti-radicalism. Stage 2: Design: In this stage, we formulated specific goals to determine the sequence of material and expert judgment. Stage 3: Develop: Developing the cinema of anti-radicalism was designed based on the previous stage. It was started by creating the scenario, took the scenes of the cinema and finished the product. Before the cinema was implemented in the teaching and learning process, it had been assessed by the ICT digital learning experts and the English lecturers as English teaching experts to gain some valuable suggestions dealing with this product. Stage 4: Disseminate: The last process of this study was dissemination. We played the cinema in the classroom for subject English 1 learning. After watching the cinema, students did some discussion about the content of the cinema and also criticized the cinema. Furthermore, we also disseminated this product in the academic forum and proposed to get HKI.

There were 5 scenes in this cinema with a duration of 15 minutes. The cinema revealed the story of bu Nyai's life with her family, the activities bu Nyai when she taught her santri, and her relationship with other religious leaders and the community in creating inter-religious harmony. The actors involved in this cinema were bu Nyai and her family, the Islamic boarding school santri of Edi Mancoro, the society, foreigner, and religious leaders such as priests and monks. Below were some parts of the scene in the cinema. 


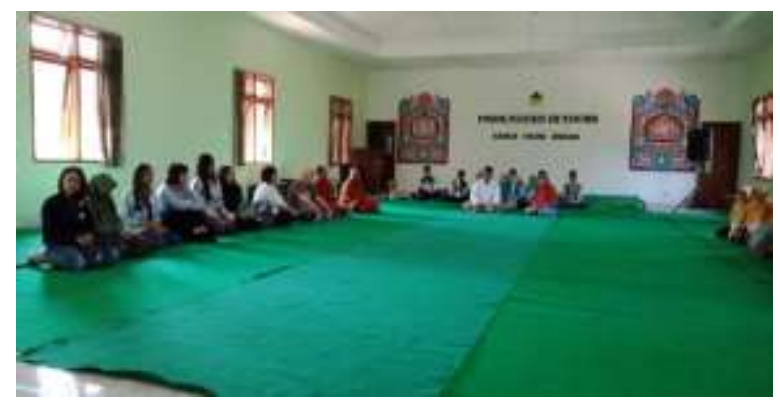

Figure 2. Part of the Inter-religious Live In scene.

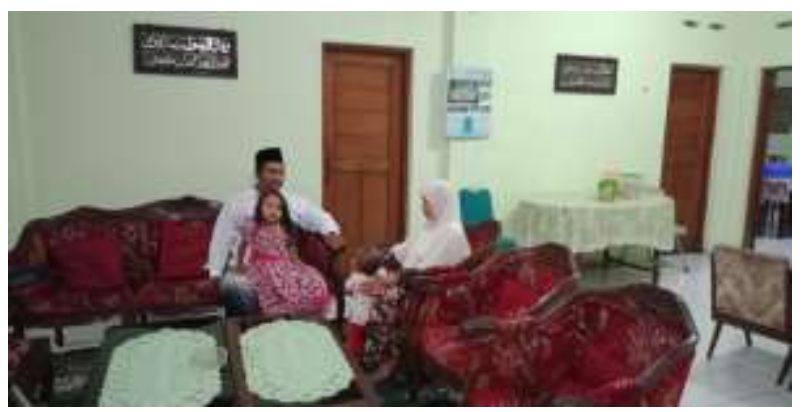

Figure 3. Part of Kyai and Nyai's discussion scene

All the contents in this cinema had been validated by expert judgment; 2 English lecturers and also ICT experts. In the first stage validation process, there were some notes to be revised, such as; the audio, the duration of the cinema and also some cinematography. Based on the results of the validation of the experts, we revised the cinema products, edited then perfected it. Moreover, after the cinema had passed the validation process, the cinema was already feasible to be used as a medium of learning English in English courses 1 for semester 1 students in English Education Department.

Based on observations during the students watched this cinema, we wrote several notes; First, the students were very enthusiastic when watching this cinema. They focused on watching the cinema from beginning to finish. There was a part of the scene in the cinema that touched the hearts of students when the figure of bu Nyai was telling about her life. On the contrary, when they saw bu Nyai interacted with her family, they turned into the feeling of her attitudes. When Bu Nyai interacted with other religious leaders such as monks and priests, students felt amazed by the utterances delivered by Bu Nyai. Those showed the existence of emotional involvement in students while watching the cinema. After watching this cinema, students delivered their impressions and views about this cinema by speaking one-on-one in front of the class using English. They could fluently express their views about this cinema. By watching this cinema, students unconsciously also developed their speaking skills in giving opinions, views and moral messages contained in this cinema. Fourth, the message from the cinema about anti-radicalism based on gender perspective had been conveyed well to students. Fifth, by using cinema media, it was easier for students to develop language skills, especially speaking skills, and character building. Meanwhile, according to the result of the interview with students, we concluded 
several notes: all the students said they interested in the cinema. They thought that this cinema was very valuable, students assessed being able to enjoy this cinema in terms of audio, cinematography and the content; the students also said that they gained new knowledge that never found before in the previous English textbook material. They also learned about sociolinguistics in Islam with a gender perspective. Besides, reviewing from the sociolinguistics study which discussed the relationship between social relations and language, this research had a real contribution, especially from the perspective of gender. This cinema described the story of a prototype of Muslim women leaders in the millennial era as the way of deradicalization in Indonesia. The publication of this cinema could be an inspiration for all elements, especially Muslim women leaders in Indonesia and the society. Moreover, this cinema also could be a da'wah media for society since it discussed gender and age, where Bu Nyai could be a role model to deliver the message of peace to society. Then, this cinema also taught about character education such as nationalism, patriotism, tolerance and inter-religious harmony.

\section{CONCLUSION}

The development of sophisticated technology in this 4.0 industrial revolution era could be an alternative for those who wanted to further develop their English language learning skills by utilizing the technology. One of them was by using cinema as an interesting alternative media in teaching English. The cinema made in this study was an innovation in internalizing language and issues which were currently developing in Indonesia such as radicalism. This cinema was sociolinguistics studies context which also as a model to build character aspects for students.

\section{REFERENCES}

[1] W. Foundation, "Tentang Wahid Foundation," 2017. [Online]. Available: http://wahidfoundation.org/index.php/page/index/About-Us. [Accessed: 09-Jan-2020].

[2] Menteri Pendidikan Nasional, Permendiknas No 17 Tahun 2010. 2010, pp. 1-9.

[3] E. Elfi, "Integrating Islamic messages in the English teaching for moeslem students in Indonesia," in Integration and Interconnection of Sciences "The Reflection of Islam Kaffah,”2016, no. October 2016, pp. 221-230.

[4] R. Phillipson, Linguistic imperialism. Oxford University Press, 1992.

[5] A. B. Briggs, Kindergartens Using Digital Cameras to Label Their Surroundings to Increase Word Recognition Abilities. Sacramento: California State University, 2010.

[6] S. Nusir, I. Alsmadi, M. Al-Kabi, and F. Shardqah, "Designing an interactive multimedia learning system for the children of primary schools in Jordan," 2011 IEEE Glob. Eng. Educ. Conf. EDUCON 2011, pp. 45-51, 2011, doi: 10.1109/EDUCON.2011.5773111.

[7] K. Sanford and L. Madill, "Understanding the power of new literacies through video game play and design," Can. J. Educ., vol. 30, no. 2, pp. 432-455, 2007, doi: $10.2307 / 20466645$.

[8] Rohmah Zuliati, "Incorporating Islamic Messages in the English Teaching in the Indonesian Context," Int. J. Soc. Sci. Educ., vol. 2, no. 2, pp. 2223-4934, 2012.

[9] B. Islam, A. Ahmed, K. Islam, and A. K. Shamsuddin, "Child Education Through Animation: An Experimental Study," Int. J. Comput. Graph. Animat., vol. 4, no. 4, pp. 43-52, 2014, doi: 10.5121/ijcga.2014.4404.

[10] A. Kirtkpatrict and D. Prescott, "Whose Course is it anyway? Why We Need a New ELT Teacher Training Course.," in CULI's Third International Conference, 1995. 
[11] L. R. Gay, Educational research : competencies for analysis and application. London: Merrill Pub. Co, 1987.

[12] "Sociolinguistics - Wikipedia." [Online]. Available: https://en.wikipedia.org/wiki/Sociolinguistics. [Accessed: 09-Jan-2020].

[13] F. Coulmas, Sociolinguistics: The study of speakers' choices, second edition. Cambridge University Press, 2010.

[14] M. D. Gall, W. R. Borg, and J. P. Gall, Educational Research: An Introduction. New york: Alin and Bacon, 2003.

[15] S. Thiagarajan, Instructional Development for Training Teachers of Exceptional Children. 1974. 